\title{
Reproductive ecology of Shorea roxburghii G. Don (Dipterocarpaceae), an Endangered semievergreen tree species of peninsular India
}

\author{
A.J. Solomon Raju ${ }^{1}$, K. Venkata Ramana ${ }^{2} \&$ P. Hareesh Chandra ${ }^{3}$ \\ 1,2,3 Department of Environmental Sciences, Andhra University, Visakhapatnam, Andhra Pradesh 530003, India \\ Email: ${ }^{1}$ ajsraju@yahoo.com (corresponding author), ${ }^{2}$ vrkes.btny@gmail.com, ${ }^{3}$ hareeshchandu@gmail.com
}

Date of publication (online): 26 September 2011 Date of publication (print): 26 September 2011 ISSN 0974-7907 (online) | 0974-7893 (print)

Editor: K.R. Sasidharan

\section{Manuscript details:}

Ms \# 02763

Received 13 April 2011

Final received 19 July 2011

Finally accepted 29 August 2011

Citation: Raju, A.J.S., K.V. Ramana \& P.H Chandra (2011). Reproductive ecology of Shorea roxburghii G. Don (Dipterocarpaceae), an Endangered semievergreen tree species of peninsular India. Journal of Threatened Taxa 3(9): 2061-2070.

Copyright: ( A.J. Solomon Raju, K. Venkata Ramana \& P. Hareesh Chandra 2011. Creative Commons Attribution 3.0 Unported License. JoTT allows unrestricted use of this article in any medium for non-profit purposes, reproduction and distribution by providing adequate credit to the authors and the source of publication.

Author Detail: see end of this article

Author Contribution: AJSR has done part of the field work and write-up of the manuscript while VR and $\mathrm{HC}$ were involved in field work and provided assistance in writing.

Acknowledgements: This study is a part of the research work carried out under an All India Coordinated Research Project on Reproductive Biology of RET Tree species funded by the Ministry of Environment \& Forests, New Delhi sanctioned to AJSR. We thank Dr. V.V. Ramamurthy, Division of Entomology, Indian Agricultural Research Institute, New Delhi, for identification of some insects reported in the present study.
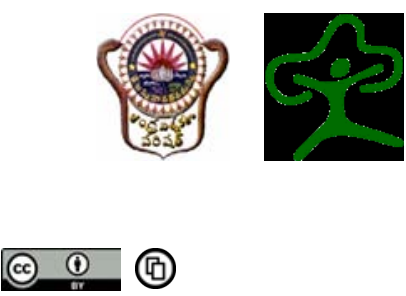

OPEN ACCESS | FREE DOWNLOAD
Abstract: Shorea roxburghii is an Endangered semievergreen tree species restricted to peninsular India in the Eastern Ghats. Leaf shedding and leaf flushing are annual events while flowering is not annual, but when it does flower, in March, it shows massive blooming. Massive blooming, drooping inflorescence with pendulous flowers, ample pollen production, gradual pollen release as a function of anther appendage and aerodynamic pollen grains - all suggest anemophily. The characteristics of nectar secretion, hexose-rich sugars and amino acids in nectar are additional adaptations for entomophily. The plant is functionally self-incompatible, obligately outcrossing and ambophilous. The natural fruit set does not exceed $15 \%$ despite the plant being ambophilous. Scarabaeid beetle by causing flower damage and bruchid beetle by using buds, flowers and fruits for breeding greatly affect fruit set rate and thus the success of sexual reproduction in this plant species is also affected. Seeds are non-dormant, the embryo is chlorophyllous while the fruits are on the plant. Healthy seeds germinate as soon as they reach the forest floor but their establishment is seemingly affected by resource constraints due to the rocky habitat. The study suggests that non-annual flowering, massive flowering for a short period, high bud/flower and fruit infestation rate, absence of seed dormancy and rocky habitat could attribute to the endangered status of S. roxburghii.

Keywords: Ambophily, anemochory, bud, flower and fruit predation, self-incompatibility, Shorea roxburghii.

\section{INTRODUCTION}

Shorea is an important timber genus with most of its species classified as Critically Endangered in the IUCN Red List (IUCN 2011). James \& Chan (1991) stated that Shorea species are insect pollinated; a variety of insects have been implicated in its pollination. Shorea species occurring within one habitat and sharing the same insect pollinators, flower sequentially to prevent competition for pollinators (James \& Chan 1991). S. megistophylla, an endemic canopy tree species in Sri Lanka has been reported to be pollinated by Apis bees (Dayanandan et al. 1990). Shorea flowers with large yellow elongate anthers have been reported to be pollinated by bees while those with small, white anthers by thrips. Thrips are implicated as pollen vectors for several Malaysian species of Shorea (Appanah \& Chan 1981). In India, the genus Shorea is represented by $S$. assamica, S. robusta, S. tumbuggaia and S. roxburghii. S. robusta is an anemophile with explosive pollen release pollination mechanism (Atluri et al. 2004). S. tumbuggaia is a Data Deficient (Ashton 1998a) semievergreen tree species restricted to the southern Eastern Ghats in Andhra Pradesh and Tamil Nadu. It is anemophilous as well as anemochorous (Solomon Raju et al. 2009). S. roxburghii is a semievergreen Endangered (Ashton 1998b) tree species of peninsular India, which is included in the list of medicinal 
plants of conservation areas of Eastern Ghats of Andhra Pradesh (Rani \& Pullaiah 2002; Jadhav \& Reddy 2006). It is a constituent species of southern tropical dry deciduous forests in the Eastern Ghats (Chauhan 1998) and extends its distribution to dry evergreen or deciduous forest and bamboo forest, often on sandy soils in Burma, Thailand, Indochina and peninsular Malaysia in tropical Asia. It is an important timber and resin source; the latter is used as a stimulant and for fumigation (Ashton 1963, 1982; Anonymous 1985). There is absolutely no information on the reproductive ecology of this species, hence the present study was contemplated to provide a comprehensive account on its reproductive ecology and discuss the same in the light of relevant published information.

\section{MATERIALS AND METHODS}

Shorea roxburghii populations growing on rocky areas at Akasaganga, Papavinasanam and Talakona sites of Tirupati Hills of the Eastern Ghats (Talakona$13^{\circ} 40^{\prime} \mathrm{N} \& 7^{\circ} 19^{\prime} \mathrm{E}$, elevation $744 \mathrm{~m}$; Akasaganga and Papavinasanam are $3 \mathrm{~km}$ apart from each other but both the sites are about $80 \mathrm{~km}$ to the west of Talakona) in Andhra Pradesh State were selected for study during 2008-2010. The study aspects included flowering, fruiting, seed dispersal and seedling ecology. Ten inflorescences, two each from five trees were tagged and followed for their flowering duration. Thirty flowers collected from six trees were used to record floral details. Mature flower buds on ten inflorescences were tagged and followed for recording the time of flower opening. The same flowers were followed for recording the time of anther dehiscence. The pollen grain characteristics were recorded by consulting the book of Bhattacharya et al. (2006). Pollen production per flower was calculated following the method described by Cruden (1977). Pollen fertility was assessed by staining them in $1 \%$ acetocarmine. Stigma receptivity and nectar volume, sugar concentration and sugar types were recorded by following the protocols given in Dafni et al. (2005). Nectar was also analyzed for amino acid types by following the paper chromatography method of Baker \& Baker (1973). Fifty mature buds, five each from 10 inflorescences on five trees were bagged a day before anthesis, without manual self pollination, to know whether fruit set occurs through autogamy. Another set of 50 mature buds was selected in the same way, then emasculated and bagged a day prior to anthesis. The next day, the bags were removed and the stigmas were brushed with freshly dehisced anthers from the flowers of the same tree and rebagged to know whether fruit set occurs through geitonogamy. Five trees each at Akasaganga, Papavinasanam and Talakona were selected for manual cross-pollination and open-pollination. Fifty flowers were used per tree for manual cross-pollination. For this, mature buds were emasculated and bagged a day prior to anthesis. The next day, the bags were removed; freshly dehisced anthers from the flowers of another tree were brushed on the stigma and rebagged. Ten inflorescences on each tree were tagged for fruit set in open pollination. The bagged flowers and tagged inflorescences were followed for four weeks to record the results. Observations on flower visitors and their foraging activity period with reference to pollination were made by using binoculars. The insect species visiting the flowers and the forage sought by them were recorded. Five-hundred flowers collected at random from 20 trees were examined to record the percentage of flower damage by the scarabaeid beetle. Another set of 500 flowers collected from 20 trees were examined for flower infestation rate by the bruchid beetle. Further, 385 fallen fruit were collected to record fruit infestation rate by the same bruchid beetle. Fruit set rate, maturation and fruit fall timing and dispersal aspects were observed in the field. Field observations were made to record natural seed germination and establishment rate. One-hundred mature fruits collected from the trees were sown in an experimental plot to record seed germination rate.

\section{RESULTS}

Shorea roxburghii is a semievergreen tree species. Leaf shedding, flowering and leaf flushing are annual events in this species. Leaf shedding occurs during the winter season from mid-November to midFebruary (Image 1a). About a week later, leaf flushing begins and ends in July (Image 1b). Flowering begins in the first week of March and ceases by the end of March at population level. A tree flowers for about three weeks only. Trees grow up to a height of $12 \mathrm{~m}$ and flowering at canopy level is quite visible 

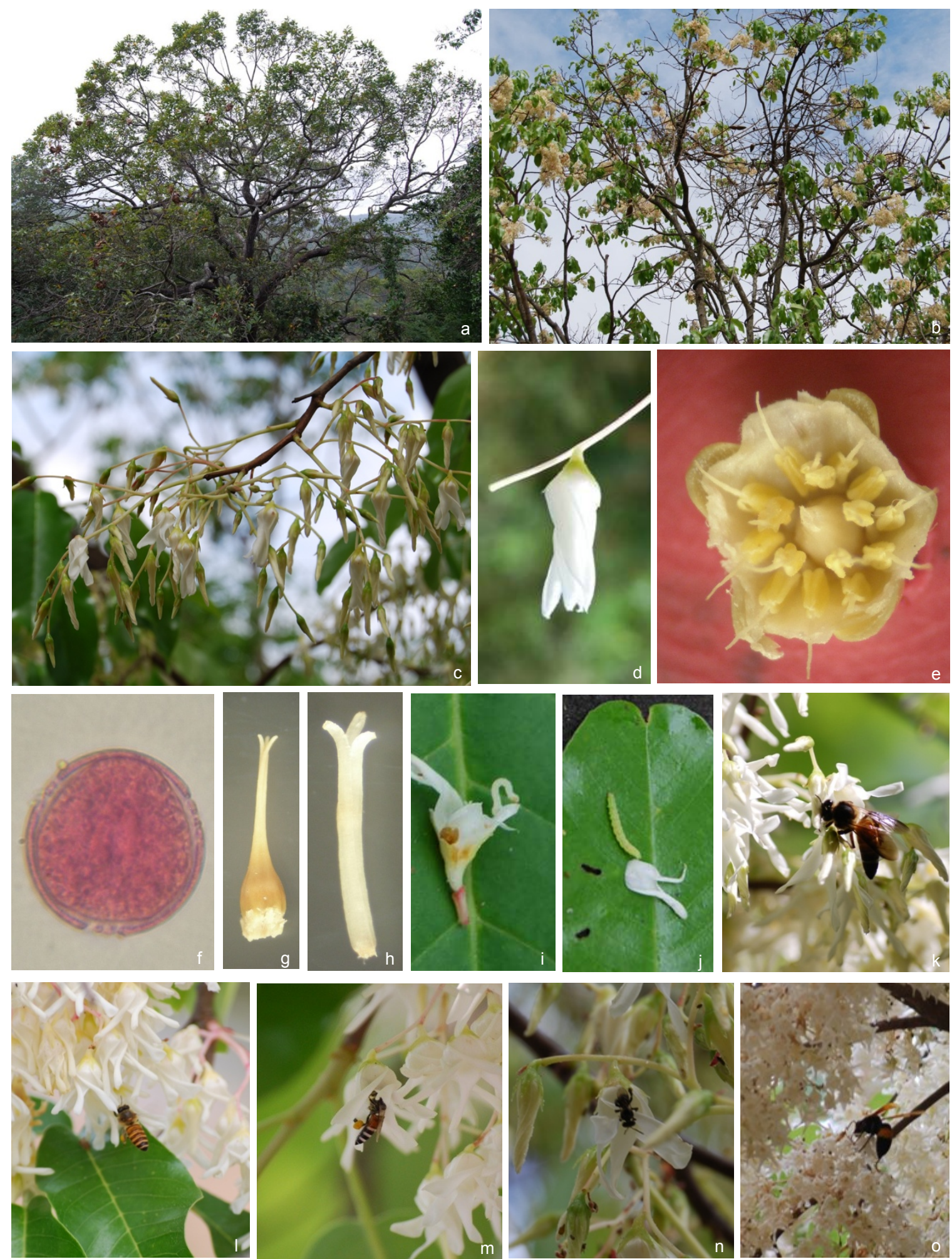

Image 1 - Shorea roxburghii: a - Leaf shedding stage; b - Leaf flushing followed by flowering; c - Flowering paniculate drooping inflorescence; $d$ - Flower; e - Stamen arrangement and anthers equipped with appendage; $f$ - Pollen grain g - Ovary with style and stigma; $\mathbf{h}$ - Trifid stigma; i \& j - Bruchid beetle larva in mature buds; $k$-o - Insect foragers k - Apis dorsata; I - Apis cerana; $\mathrm{m}$ - Apis florea; $\mathrm{n}$ - Trigona iridipennis; o - Vespa cincta.

from a long distance due to the presence of newly emerging bright green leaves. Inflorescence is a drooping terminal or axillary racemose panicle with an average of $37 \pm 6$ flowers which anthese over an 
average period of $5 \pm 2$ days (Image 1c). Flowers are pedicellate, hang downwards, milky white with light reddish tinge, fragrant, $2 \mathrm{~cm}$ long and $3 \mathrm{~cm}$ across, bisexual, zygomorphic, cup-like at base and star-like terminally (Image 1d). Sepals are five, blunt-lobed, $0.7 \mathrm{~cm}$ long, light green, imbricate, basally united into a cup, free terminally and persistent. Petals are five, milky white, fragrant, $2.2 \mathrm{~cm}$ long, connate at base forming a cup-like structure, free terminally. Stamens are 15 , free, arranged closely in two whorls to the base of the corolla; inner row consists of five stamens while outer row with ten stamens. They are situated below the level of stigma. Each stamen consists of a $0.2 \mathrm{~cm}$ long filament with a $0.2 \mathrm{~cm}$ long anther. Anthers are light yellow, dorsifixed but appear to be basifixed; tetrasporangiate and dehisce by longitudinal slits ca. 30min after anthesis. The connectival part of the filament of each anther extends into a $0.3 \mathrm{~cm}$ long sterile tip constituting "anther appendage" (Image 1e). The pollen production per anther is $3,379.8 \pm 196.62$ grains, and per flower it is 50,697. The pollen grains are yellow, powdery, radially symmetric, tricolporate, $24.9 \mu \mathrm{m}$ long and have reticulate exine with muri separated by lumina (Image 1f). In a flower, fertile pollen is $92 \%$ while the remaining $8 \%$ is sterile. Pollen to ovule ratio is $8,449.5: 1$. Ovary is semi-inferior, syncarpous with three united locules having a total of six light yellow ovules on axile placentation. Style is $0.6 \mathrm{~cm}$ long, semi-wet and extended into a trilobed stigma (Image 1g,h). The petals, stamens, style and stigma fall off on the third day while the sepals remain until the fruits fall off.

The flower opening occurs at $0500-0600 \mathrm{hr}$ while anther dehiscence occurs after three hours. The petals being twisted in bud gradually unfold and spread upwards gradually giving a star-like appearance. The cup-like flower base with stamens is exposed to the outside environment. The flowers are nectariferous and each flower produces $2.15 \pm 0.28 \mu \mathrm{l}$ of nectar. The nectar sugar concentration is $11.7 \pm 1.9 \%$ consisting of glucose, fructose and sucrose but the first two sugar types are dominant. The nectar also contains both essential and non-essential amino acids; the essential ones are histidine, arginine, iso-leucine and threonine while the non-essentials are proline, aspartic acid, alanine, glutamic acid, glysine, tyrosine and cystine. The stigma lobes are erect and united in bud but unfold at anthesis indicating receptivity which lasts for two days by being in semi-wet state; it is dry and shows signs of withering by the end of the second day. The same duration of stigma receptivity was recorded when tested with hydrogen peroxide. The flowers in the hanging position do not allow nectar flow along the length of the corolla since it is in a minute quantity and held intact by the ovary base and staminal filaments. The pollen release from dehisced anthers was gradual when the flowers were shaken manually. The dehisced anthers became empty after 3-5 manual shakes. This gradual pollen release was considered to be an adaptation for anemophily. The insects probing the flowers for forage collection also caused the anthers to release pollen gradually. The flowers were foraged during day time by eight insect species belonging to Hymenoptera [Apis dorsata (Image 1k), A. cerana (Image 11), A. florea (Image 1m), Trigona iridipennis (Image 1n) and Vespa cincta (Image 1o)], Diptera [Helophilus sp. (Image 2a)] and Lepidoptera [Euploea core (Image 2b) and Tirumala limniace (Table 1)]. Bees were found to collect both nectar and pollen; they were regular foragers throughout the flowering season. Their foraging activity pattern showed two schedules, one during $0700-1200 \mathrm{hr}$ with hectic activity and the other during 1600-1800 hr with low activity. Wasps and fly foragers were also regular but only a few individuals visited the flowers. They foraged for nectar only during the forenoon period from 1000 to $1200 \mathrm{hr}$ (Fig. 1). Nymphalid butterflies were also exclusive nectar foragers but their visits were not consistent during the day. The data collected on the foraging visits of these foragers on a given day

Table 1. List of insect foragers on Shorea roxburghii

\begin{tabular}{|l|l|l|}
\hline Family & Scientific Name & Common Name \\
\hline Hymenoptera & Apis dorsata & Rock Bee \\
\hline Apidae & Apis cerana & Indian Honey Bee \\
\hline & Apis florea & Dwarf Honey Bee \\
\hline & Trigona iridipennis & Stingless Bee \\
\hline Vespidae & Vespa cincta & Potter Wasp \\
\hline Diptera & Helophilus sp. & Hoverfly \\
\hline Syrphidae & \multicolumn{2}{|l}{} \\
\hline Lepidoptera & Euploea core & Common Indian Crow \\
\hline Nymphalidae & Tirumala limniace & Blue Tiger \\
\hline \multicolumn{2}{|l|}{}
\end{tabular}



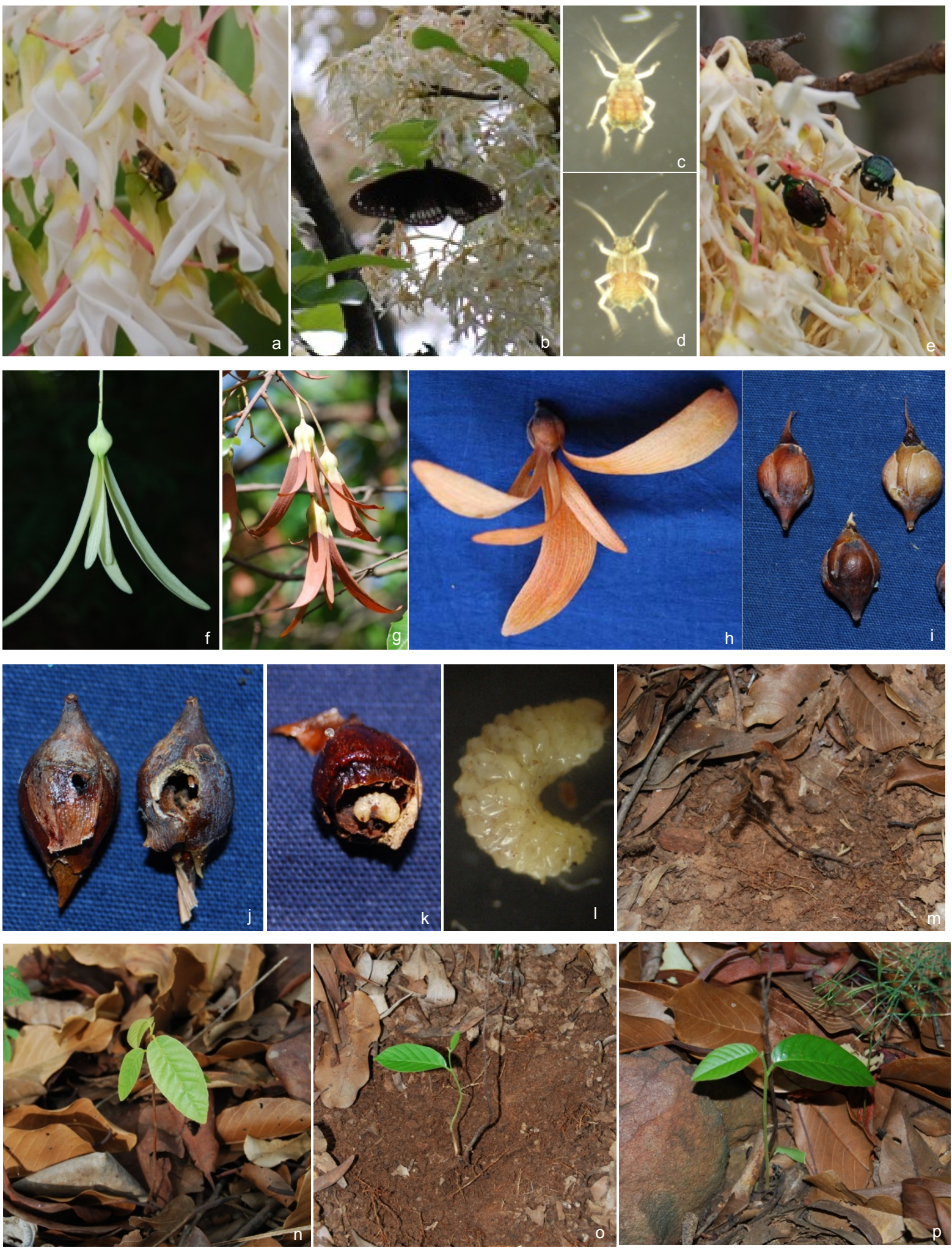

Image 2. Shorea roxburghii: a - Helophilus sp.; b - Euploea core, c - e - Juvenile and adult Popillia impressipyga; $\mathrm{f}$ - Early stage of fruit; $\mathrm{g}$ - Maturing fruit; $\mathrm{h}$ - Mature fruit; i - Fruit without calyx; $\mathrm{j}$ - I - Fruits infested with Bruchid beetle larva; $m$ - Seedling mortality; $n-p$ - Growing seedling.

indicated that bees accounted for $77 \%$, wasps and flies each $5 \%$ and butterflies $13 \%$ of the total foraging Journal of Threatened Taxa | www.threatenedtaxa.org | September 2011 | 3(9): 2061-2070 visits (Fig. 2). All insects after landing probed the flowers for nectar and/or pollen. Both nectar and 


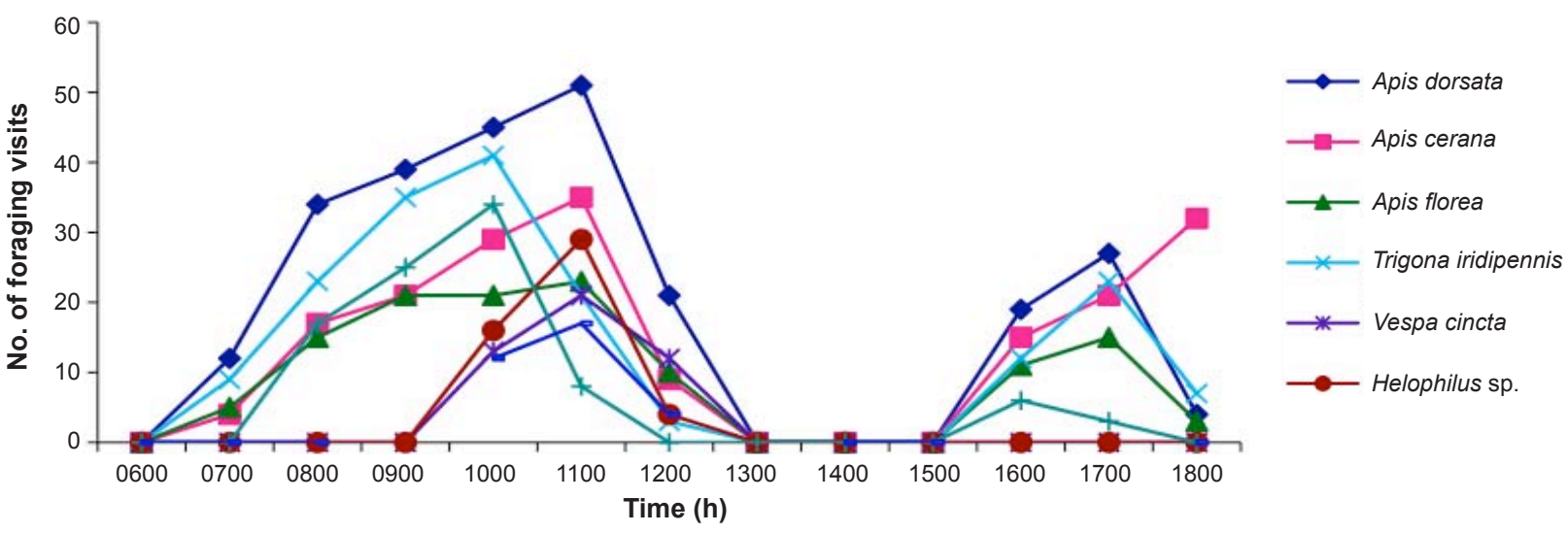

Figure 1. Hourly foraging activity of insects on Shorea roxburghii

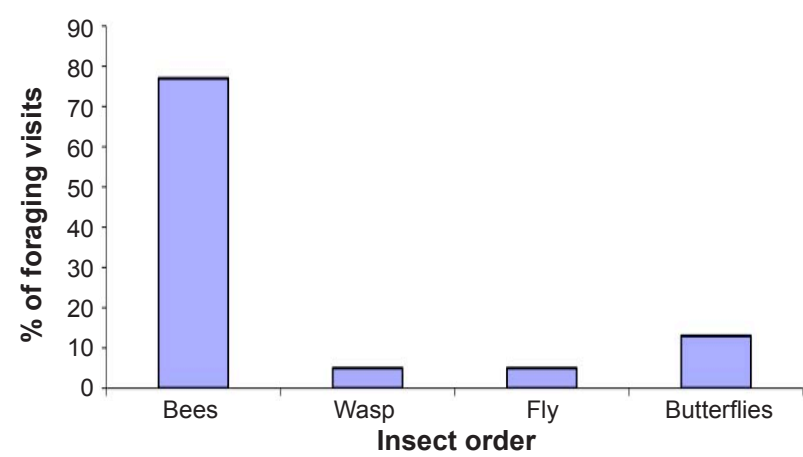

Figure 2. Forgaing visits of different categories of insects on Shorea roxburghii

pollen collecting insects were found to be contacting the anthers and stigma invariably while collecting the forage and such contact with the sex organs was considered to be resulting in pollination. Trigona bees tended to stay mostly on the same tree for forage collection effecting mostly selfpollinations while Apis bees and wasps made frequent inter-tree flights in search of more pollen/nectar causing cross-pollination simultaneously. The flies tended to forage mostly on the same tree; it could effect mostly selfpollinations. The nymphalid butterflies being inconsistent foragers also made frequent inter-tree flights in search of nectar and in doing so effecting crosspollinations.

Further, swarms of Coleopteran Popillia impressipyga (Scarabaeidae) (Image 2c-e) were found to be consistent flower-feeders. Its newly emerging offspring especially juveniles fed on the sap of floral petals while the adults on all parts of the flowers effecting the success of sexual reproduction to a great extent. The breeding site of this beetle was not known. Flower damage rate by this beetle was $48 \%$ and these flowers subsequently fell off. An unidentified bruchid beetle was found to be breeding in flowers and the flowers hosting this beetle were found subsequently to be falling off without fruit set. In each flower, there was only one green coloured larva of this beetle (Image $1 \mathrm{i}, \mathrm{j}$ ) and the larva falls off along with the petals and stamens. The larvae upon reaching the ground pupate within the soil to produce adults. Flower infestation rate by this beetle was $36.6 \%$.

The manual pollinations for autogamy and geitonogamy did not set fruit while those of xenogamous pollinations set fruit ranging from 15.7 to $28.4 \%$. The fruit set was $8.4-15.4 \%$ in openpollinations (Table 2). The number of fruits set in open-pollinations at inflorescence level was $5.03 \pm 0.52$. Each fruit produces only one seed against the actual number of six ovules. The fruits take about five weeks to mature and fall to the ground by the end of May (Image 2f-g). They are winged and wings represent sepals which are accrescent in that they are thickened and three of them expand into wings and are larger than the other two sepals (Image 2h). They are $1.41 \pm 0.29$ gm in weight while the fruits without winged sepals are $1.18 \pm 0.26$ (Image 2i). The fruits show colour change from green to brown to dark brown gradually and finally become dry. The fruit wall is free from calyx, woody, with a thin inner membranous lining invaginated into the folds of cotyledons and split into two parts at the apex. The seed is non-dormant and the embryo is chlorophyllous.

The fruits also contained the same bruchid beetle which was found in flowers. Each fruit contained a single larva which was creamy white in colour. The larva feeds on the internal soft parts of the developing 
Table 2. Fruit set under open pollinations and manual xenogamous cross-pollinations in Shorea roxburghii at three sites in the Tirumala Hills

\begin{tabular}{|c|c|c|}
\hline Tree number & $\begin{array}{c}\text { Per cent fruit set } \\
\text { (open pollination) }\end{array}$ & $\begin{array}{c}\text { Per cent fruit } \\
\text { set (hand cross- } \\
\text { pollination) }\end{array}$ \\
\hline AG1 & 8.5 & 26.4 \\
\hline AG2 & 12.4 & 21.6 \\
\hline AG3 & 9.4 & 15.7 \\
\hline AG4 & 7.3 & 28.4 \\
\hline AG5 & 15.4 & 21.5 \\
\hline PV1 & 13.5 & 17.5 \\
\hline PV2 & 12.6 & 18.5 \\
\hline PV3 & 7.3 & 21.3 \\
\hline PV4 & 9.8 & 18.3 \\
\hline PV5 & 11.8 & 19.4 \\
\hline TK1 & 8.4 & 22.6 \\
\hline TK2 & 11.7 & 24.5 \\
\hline TK3 & 13.5 & 28.4 \\
\hline TK4 & 6.5 & 19.4 \\
\hline TK5 & 14.8 & 27.3 \\
\hline
\end{tabular}

AG - Akasaganga; PV - Papavinasanam; TK - Talakona

fruit and emerges from the exit hole drilled by it (Image 2j-1). When the fruit falls to the ground, the larva leaves the fruit through the hole for pupation in the soil. The pupal stage was observed for six weeks but there was no emergence of adult in the lab set up; this long period was considered as dormant stage of pupa for the emergence of the adult when conditions are favourable in the forest soil. Further, in $2 \%$ of fallen fruits, the larva remains inside to pupate and produce the adult beetle. Fruit infestation rate was $87 \%$. The dry winged fruits fall to the ground and disperse within a $10-20 \mathrm{~m}$ area of the tree due to wind action. Healthy seeds germinate in field conditions following monsoon showers. A small number of seedlings withered initially (Image $2 \mathrm{~m}$ ) while most of them perished after some growth and development. Finally, a few seedlings grew continually (Image 2np). Seed germination rate was $8 \%$ in the experimental plot.

\section{DISCUSSION}

Shorea roxburghii is an important constituent of deciduous forests in the Eastern Ghats. It is a semievergreen tree species due to its very brief leafless state during the dry season. Leaf shedding, leaf flushing and flowering occur almost sequentially one after the other. Leaf flushing however extends beyond fruit dispersal. In S. robusta and S. tumbuggaia also, these three phenological events occur in sequence (Singh \& Kushwaha 2005; Raju et al. 2009). In S. roxburghii, the flowering is not an annual event as only a few trees flowered at each study site but leaf shedding and flushing occurred annually. Flowering occurred on all branches of the tree. In S. tumbuggaia also, flowering is not annual and in the flowering individuals, the flowering is restricted to branches which are exposed to sunlight (Raju et al. 2009). The flowering period is very brief in $S$. roxburghii while its duration is further reduced in S. tumbuggaia (Raju et al. 2009). In both the species, the flowering pattern represents the massive flowering pattern in which more flowers are produced per day during the flowering period (Gentry 1974; Opler et al. 1980). Mass flowering is considered as a property of the individuals of a plant species (Bawa 1983) and this pattern of flowering may have evolved among individuals of S. roxburghii for effective pollen movement between trees. The new leaves are known for their photosynthetic efficiency and hence have the ability to provide the required photosynthate to the growing fruits.

In $S$. roxburghii, the flowers are morphologically and functionally bisexual. The absence of fruit set in autogamy and geitonogamy suggests that the plant is self-incompatible. The sterile pollen present in the flowers appears to be a derived trait to promote self-incompatibility. The protogyny is an important functional mechanism to promote out-crossing but it is weak in this species. Bertin \& Newman (1993) stated that protogyny is a characteristic associated with selfcompatible anemophilous flowers to reduce selfing rate. S. roxburghii being self-incompatible exhibits weak protogyny and hence it is a residual character and does not serve to achieve cross-pollination. On the contrary, S. tumbuggaia and S. robusta are selfcompatible anemophiles; but protogyny is weak in the former while it is strong in the latter species (Atluri et al. 2004; Raju et al. 2009). In S. roxburghii, the drooping inflorescence, hanging flowers with compactly arranged anthers at the base and held above by anther appendages and the exposed cup-like flower base collectively aid in the gradual dispersal of pollen by wind. Gradual pollen release occurs when the flowers 
are manually shaken; it suggests that wind force does not make the anthers release the pollen at once, hence there is an in-built device for the gradual and economical release of pollen from oscillating flowers due to wind force. As the flowers are at the canopy level, the wind force can easily make flowers release pollen into the air and then carry the same to the receptive stigmas of flowers on different trees. The pollen grain size is a characteristic typical aerodynamic particle, which permits effective wind transport and deposition on the stigma through impaction (Gregory 1973; Reddi 1976) and the characters such as reticulate exine and muri separated by lumina may reduce terminal velocity and contribute to the increased dispersal range of the pollen (Niklas 1985). Synchronous anthesis and high pollen production enable anemophily to be more effective. In S. robusta and S. tumbuggaia also, a similar pollen release mechanism and anemophily exist (Atluri et al. 2004; Raju et al. 2009). The study sites experienced moderate turbulent atmospheric conditions especially during the forenoon period and this favoured efficient transport of the entrained pollen (Mason 1979).

The self-compatible S. robusta and S. tumbuggaia are strictly anemophilous. The flowers of both the species do not secrete nectar and hence pollen is the only floral reward for the insects which visit them. Atluri et al. (2004) reported that honey bees may visit $S$. robusta for pollen collection and their foraging activity is of no use to this plant. Raju et al. (2009) reported that the stingless bee, Trigona iridipennis visits $S$. tumbuggaia for pollen collection and its foraging activity is important for self-pollination due to its slow mobility. The fruits formed from selfed-flowers have been considered to be abortive. In $S$. roxburghii, the flowers are nectariferous and produce hexose-rich nectar with low sugar concentration. Since the flowers offer both nectar and pollen, they attract nectar and pollen foraging bees, nectar foraging wasps, flies and butterflies; flies are important for self-pollination and all the other insects for both self-and cross-pollination. Their foraging activity on $S$. roxburghii flowers is not in line with the generalization that they visit flowers rewarded with sucrose-rich nectar with high sugar concentration (Baker \& Baker 1982, 1983; Cruden et al. 1983). The nectar of $S$. roxburghii is also a source of four of the ten essential amino acids and seven nonessential amino acids (DeGroot 1953). They add taste to the nectar and serve as an important cue for insects to pay visits to the flowers; and the insects while collecting the forage effect pollination. The amino acids are especially important for the growth and development of flower-visiting insects (DeGroot 1953). Therefore, S. roxburghii being a self-incompatible species has evolved to produce nectar with sugars and amino acids as rewards to attract insects for increasing the crosspollinate rate. The ability to have both anemophily and entomophily is adaptive for $S$. roxburghii to set fruit to permitted level through cross-pollination. The function of a pollination system involving both wind and insects as vectors of pollen transfer is referred to as 'ambophily' (Culley et al. 2002) and hence $S$. roxburghii is functionally ambophilous.

S. roxburghii flowers attract two beetle species. The scarabaeid beetle causes flower damage by sucking sap from petals and the damaged flowers whether pollinated or un-pollinated fall off. The bruchid beetle uses the floral buds for its breeding. A single larva emerges when the buds mature and bloom; such buds and flowers fall off together with the larvae without fruit set. The bud and flower infestation rate by these two beetle species is very high and hence have a great bearing on the success of sexual reproduction in $S$. roxburghii.

In $S$. roxburghii, the fruits mature quickly during the dry season. They are winged, light-weight and characteristically produce a single seed. The embryo is chlorophyllous while on the parent plant, suggesting that the seed is non-dormant and such a characteristic may aid in better survival in unpredictable habitats with irregular supply of light, nutrients and water during the germination period (Maury 1978; MauryLechon \& Ponge 1979). A similar situation exists in S. tumbuggaia (Raju et al. 2009). The winged character of fruits is seen in most dipterocarps and it is an important adaptation for dissemination by wind (Ashton 1982). The winged structure of the sepals allows 1-seeded fruits to gyrate toward the ground and hence the seed dispersal is anemochorous. Seeds disperse by wind to a short distance only, due to the semi-closed nature of the canopy cover of the forest. The dispersal of winged fruits takes place much more efficiently by wind if the forest is of the open, seasonal, dry deciduous type (Maury-Lechon \& Curtet 1998). The seeds fallen on the ground have no possibility for further dispersal by the sweeping action of the wind due to litter accumulation and grass growth in 
the study sites during rainy season. In S. tumbuggaia, seed dissemination by wind takes place up to a distance of $10 \mathrm{~m}$ (Raju et al. 2009) and up to $2 \mathrm{~km}$ in S. albida (Ashton 1982).

Different insect species attack seeds of Shorea species during their development (Singh 1976). Insect pests attack at the pre- or post-dispersal stage of the seed; in the pre-dispersal stage, the pest attacks the fruit on the tree before dispersal while in the postdispersal stage, the pest attacks fruits on the ground (Toy 1988). In S. roxburghii, the same bruchid beetle which uses buds and flowers for breeding also attacks at an early stage of the development of the fruit. Its larva leaves through the exit hole created by it when the mature fruits fall to the ground. It pupates in the soil and perhaps, produces an adult only when favourable conditions return to the forest floor to repeat its life cycle. Khatua \& Chakrabarti (1990) reported that many bruchid species spend a dormant stage as pupae in the soil and it holds true in the case of the bruchid beetle which is a pest of the seeds of $S$. roxburghii. Further, in a small percentage of fallen fruits, the larva remains within, pupates and produces an adult beetle suggesting that the beetle has the ability to use the fruit for its entire life cycle. The same bruchid beetle attacks the co-occurring $S$. tumbuggaia seeds in the study sites but the per cent of infested seeds is comparatively less due to its late flowering which occurs for two weeks in the last week of April and the first week of May (Raju et al. 2009). They also reported that in India, the seed weevil Sitophilus (Calandra) rugicollis attacks seeds of Shorea robusta, survives as a dormant adult in the forest floor and emerges with the first monsoon rain, which coincides with the commencement of seed fall (Khatua \& Chakrabarti 1990).

Mass fruiting appears to favour seed predators, but it can also be a strategy to escape complete seed destruction (Janzen 1974). Seed predation can be very high, and the crop can be completely wiped out. Natawiria et al. (1986) observed that weevils (Curculionidae) damage $40-90 \%$ of the seeds of Shorea pauciflora, S. ovalis, S. laevis and S. smithiana. In $S$. tumbuggaia, seed damage is $70 \%$ and only about half of the remaining healthy seed crop established seedlings in the forest (Raju et al. 2009). In S. roxburghii, seed predation is $87 \%$ suggesting that this tree is threatened by bruchid beetle in terms of reproductive success.

In $S$. roxburghii, fruit set in open pollination is up to $15 \%$ while it has almost doubled in manual crosspollination. This suggests that fruit set does not exceed beyond $30 \%$ even if the cross-pollination rate increases by wind and insects. The tree appears to have resource constraints to increase fruit set; the rocky nature of the forest floor with dry conditions during the fruit set period is perhaps the main constraint. Such a low fruit set in open-pollination has also been reported in S. tumbuggaia in the same study sites by Raju et al. (2009). The study suggests that non-annual flowering, massive flowering for a short period, high bud/ flower and fruit infestation rate, and the absence of seed dormancy could be attributed to the endangered status of $S$. roxburghii. Field situation relating to the mortality rate of seedlings and the seed germinate rate evidenced in the experimental plot also substantiate this conclusion.

\section{REFERENCES}

Anonymous (1985). Dipterocarps of South-Asia. RAPA Monograph 4/85, FAO Regional Office for the Asia and the Pacific, Bangkok, Thailand.

Appanah, S. \& H.T. Chan (1981). Thrips: the pollinators of some dipterocarps. Malaysian Forester 44: 234-252.

Ashton,P.S.(1963). TaxonomicnoteonBorneanDipterocarpaceae. Gardens'Bulletin, Singapore 20: 229-284.

Ashton, P.S. (1982). Dipterocarpaceae. Flora Malesiana Series I 9: 237-552.

Ashton, P. (1998a). Shorea tumbuggaia. In: IUCN 2011. IUCN Red List of Threatened Species. Version 2011.1. <www. iucnredlist.org >. Downloaded on 16 September 2011.

Ashton, P. (1998b). Shorea roxburghii. In: IUCN 2011. IUCN Red List of Threatened Species. Version 2011.1. <www. iucnredlist.org >. Downloaded on 16 September 2011.

Atluri, J.B., S.P.V. Ramana \& C.S. Reddi (2004). Explosive pollen release, wind pollination and mixed mating in the tropical tree Shorea robusta (Gaertn. F. (Dipterocarpaceae). Current Science 86: 1416-1419.

Baker, H.G. \& I. Baker (1973). Amino acids in nectar and their evolutionary significance. Nature (London) 241: 543-545.

Baker, H.G. \& I. Baker (1982). Some chemical constituents of floral nectar of Erythrina in relation to pollination and systematics. Allertonia 3: 25-37.

Baker, H.G. \& I. Baker (1983). A brief historical review of the chemistry of floral nectar, pp. 126-152. In: Bentley, B. \& T. Elias (eds.) The Biology of Nectaries. Columbia University Press, New York.

Bawa, K.S. (1983). Patterns of flowering in tropical plants. pp. 395-410. In: Jones, C.E. \& R.J. Little (eds.) Handbook of Experimental Pollination Biology. Scientific and Academic 
Editors, New York.

Bertin, R.I. \& C.M.Newman (1993). Dichogamy in angiosperms. Botanical Reviews 59: 112-152.

Bhattacharya, K., M.R. Majumdar \& S.G. Bhattacharya (2006). A Textbook of Palynology (Basic and Applied). New Central Book Agency (P) Ltd., Kolkata, 352pp.

Chauhan, K.P.S. (1998). Framework for Conservation and sustainable use of biological diversity: action plan for the Eastern Ghats region. Proceedings of the National Seminar on Conservation of Eastern Ghats, EPTRI, Hyderabad, 345358pp.

Cruden, R.W. (1977). Pollen-ovule ratios: a conservative indicator of breeding systems in flowering plants. Evolution 31: $32-46$.

Cruden, R.W., S.M. Hermann \& S. Peterson (1983). Patterns of nectar production and plant-pollinator coevolution. pp. 80 125. In: B. Bentley \& T. Elias (eds.) The Biology of Nectaries. Columbia University Press, New York.

Culley, T.M., S.G. Weller \& A.K. Sakai (2002). The evolution of wind pollination in angiosperms. Trends in Ecology and Evolution 17: 361-369.

Dafni, A., P.G. Kevan \& B.C. Husband (2005). Practical Pollination Biology. Enviroquest Ltd., Canada, 590pp.

Dayanandan, S., D.N.C.Attygalla, A.W.W.L.Abeygunasekara, I.A.U.N. Gunatilleke \& C.V.S. Gunatilleke (1990). Phenology and floral morphology in relation to pollination of some Sri Lankan dipterocarps. pp. 103-133. In: Bawa, K.S. \& M. Hadley (eds.) Reproductive Ecology of Tropical Forest Plants. UNSESCO, Paris and Parthenon Publishing Group, England.

DeGroot, A.P. (1953). Protein and amino acid requirements of the Honey Bee (Apis mellifera L.). Physiologia Comparata et Oecologia 3: 197-285.

Gentry, A.H. (1974). Flowering phenology and diversity in tropical Bignoniaceae. Biotropica 6: 64-88.

Gregory, P.H. (1973). Microbiology of the Atmosphere. Leonard Hill, London, 377pp.

IUCN (2011). IUCN Red List of Threatened Species. Version 2011.1. <www.iucnredlist.org>. Downloaded on 16 September 2011.

Jadhav, S.N. \& K.N. Reddy (2006). Threatened medicinal plants of Andhra Pradesh. ENVIS-SDNP Newsletter Special Issue, EPTRI, Hyderabad pp. 18-28

James, La V. \& H.T. Chan (1991). Confirmation of sequential flowering in Shorea (Dipterocarpaceae). Biotropica 23: 200 203.

Janzen, D.H. (1974). Tropical blackwater rivers, animals and mast fruiting by the Dipterocarpaceae. Biotropica 6: 69-103.

Khatua, A.K. \& S. Chakrabati (1990). Life history and seasonal activity of sal seed weevil, Sitophilus (Calandra) rugicollis Casey (Coleoptera: Curculionidae). Indian Forester 116: $63-70$.

Mason, C.J. (1979). Principles of atmospheric transport. pp. 85-95. In: R.L. Edmonds (ed.) Aerobiology: The Ecological Systems Approach, Dowden, Hitchinson \& Ross, Inc., Pennsylvania.
Maury, G. (1978). Dipterocarpacees: du fruit a la plantule. These de doctorat d'etat, Universite Paul Sabatier, Toulouse, 3 Vols. IA: 243p; IB: 432p; II: 344p.

Maury-Lechon, G. \& L. Curtet (1998). Biogeography and evolutionary systematics of Dipterocarpaceae, pp. 5-44. In: Appanah, S. \& J.M. Turnbull (eds.). A Review of Dipterocarps: Taxonomy, Ecology and Silviculture. Center for International Forestry Research, Indonesia.

Maury-Lechon, G. \& J.F. Ponge (1979). Utilisation de 1' analyse multifactorielle des correspondences pour l'etude des caracteres des fruits-germinations, embryons et plantules de Dipterocarpacees. pp. 107-127. In: G. Maury-Lechon (ed.) Dipterocarpacees: Taxonomie-Phylogenie-Ecologie, Memoires du Museum National d' Histoire Naturelle, Serie B, Botanique 26, Editions du Museum, Paris.

Natawiria, D., A.S. Kosasih \& A.D. Mulyana (1986). Some insect pests of dipterocarp seeds (in East Kalimantan and Java). Buletin Penelitian Hutan, Pusat Penelitian dan Pengembangan Hutan 472: 1-8.

Niklas, K.J. (1985). The aerodynamics of wind-pollination. Botanical Reviews 51: 328-386.

Opler, P.A., G.W. Frankie \& H.G. Baker (1980). Comparative phenological studies of shrubs and treelets in wet and dry forests in the lowlands of Costa Rica. Journal of Ecology 68: $167-188$.

Raju, A.J.S., K.V. Ramana \& K.H. Jonathan (2009). Anemophily, anemochory, seed predation and seedling ecology of Shorea tumbuggaia Roxb. (Dipterocarpaceae), an endemic and globally endangered red listed semi-evergreen tree species. Current Science 96: 827-833.

Rani, S.S. \& T. Pullaiah (2002). A taxonomic survey of trees in Eastern Ghats. Proceedings of the National Seminar on the Conservation of Eastern Ghats, EPTRI, Hyderabad, 5-15pp.

Reddi, C.S. (1976). Floral mechanism, pollen productivity and pollen incidence in Madhuca indica Gmelin, with remarks on the mode of pollination. New Botanist 3: 11-16.

Singh, K.D. (1976). Timber Seed Pests. Seed Technology in the Tropics.

Singh, K.P. \& C.P. Kushwaha (2005). Paradox of leaf phenology: Shorea robusta is a semi-evergreen species in tropical dry deciduous forests in India. Current Science 88: 1820-1824.

Toy, R.J. (1988). The pre-dispersal insect fruit-predators of Dipterocarpaceae in Malaysian rain forest. Ph.D. Thesis, University of Aberdeen, 248pp.

Author Details: Dr. A.J. Solomon Raju, Professor and Head in the Department of Environmental Sciences, is on the editorial board of several international journals. He is presently working on endemic and endangered plant species in southern Eastern Ghats forests with financial support from University Grants Commission and the Ministry of Environment and Forests, Government of India. K. Venkata Ramana and P. Hareesh Chandra are Junior Research Fellows working in All India Coordinated Research Project on Reproductive Biology of Four Rare Endangered and Threatened (RET) Tree species namely, Hildegardia populifolia (Roxb.) Schott. \& Endl., Eriolaena lushingtonii Dunn (Sterculiaceae), Syzygium alternifolium (Wt.) Walp. (Myrtaceae) and Shorea roxburghii (Dipterocarpaceae) of Andhra Pradesh, funded by the Ministry of Environment and Forests, Government of India, under the supervision of Dr. A.J. Solomon Raju. 